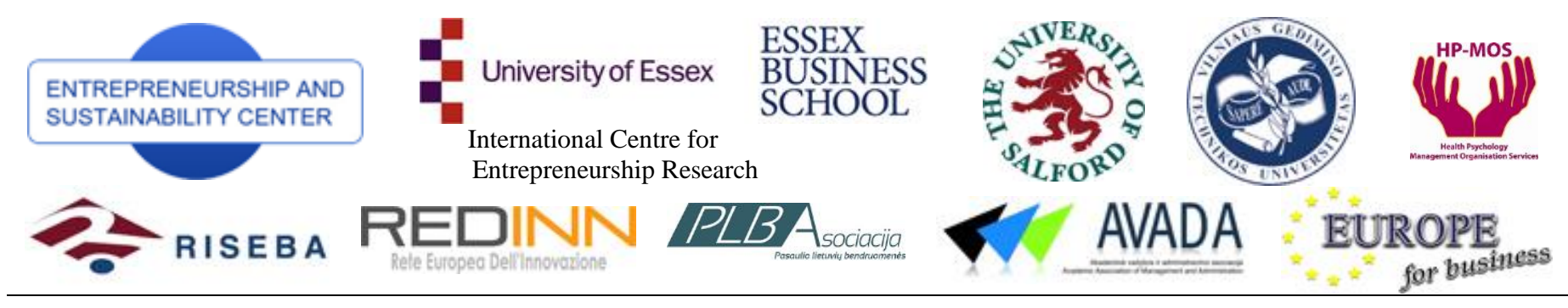

The International Journal

ENTREPRENEURSHIP AND SUSTAINABILITY ISSUES

ISSN 2345-0282 (online) http://jssidoi.org/jesi/aims-and-scope-of-research/

\title{
SUSTAINABLE SOCIAL ENTREPRENEURSHIP AND MOTIVATION: A CASE STUDY OF TWO NON-PROFIT ORGANISATIONS IN THE UK
}

\author{
Li Sun', David Luigi Fuschi² \\ ${ }^{1}$ University of Gloucestershire, The Park, Cheltenham, Gloucestershire GL5O 2RH, UK \\ ${ }^{2}$ Bridging Consulting Ltd, 36 Clevedon Drive, Earley, Reading, Berkshire, RG6 5 XE UK \\ E-mails: ${ }^{\text {sunli.lily@gmail.com; }{ }^{2} \text { d.fuschi@bridgingconsulting.com }}$
}

Received 20 January 2015; accepted 10 May 2015

\begin{abstract}
This paper presents the findings of a case study on motivation in non-for-profit (NFP) organisations in the UK with particular reference to two organisations providing services to people with learning disabilities. Quantitative data was collected from 88 respondents (68 from Company-A and 20 from Company B), through questionnaire based-surveys. Interviews were used to triangulate the data and for validation purposes. The sample used entirely falls into the employees' category and includes: permanent, temporary, full time and part-time staff but not volunteers. Findings indicate that many individuals are attracted to work in NFP organisations because of their characteristics diversity factors. Other key motivational factors include training, and flexible working arrangements. Overall findings show that people are intrinsically motivated (64\% of respondents, and over $85 \%$ enjoy this kind of work and feel listened). Company motivation was found to be low, as employees were not satisfied with the pay, still staff was motivated by intrinsic factors to remain. The findings conform to earlier studies on employees' motivation in social organisations and on pay and motivations.
\end{abstract}

Keywords: sustainability, social entrepreneurship, motivation, human resources, non-for-profit, organisation, health care

Reference to this paper should be made as follows: Sun, Li; Fuschi, D.L. 2015. Sustainable social entrepreneurship and motivation: a case study of two non-profit organisations in the UK, Entrepreneurship and Sustainability Issues 2(4): $179-187$.

DOI: http://dx.doi.org/10.9770/jesi.2015.2.4(1)

JEL Classifications: M50, O10

\section{Introduction}

Motivation as a concept has been widely debated. It is an important aspect for the organisation (both for profit and non-profit ones) and has been linked to organisation performance, job satisfaction, productivity, staff turnover, and generally to its entrepreneurship sustainability (Cooke 2000; Purcell et al. 2003; Tippet and Kluvers 2009; Laužikas, Mokšeckienė 2013; Moskvina 2013; Wahl, Prause 2013; De Alencar, Almeida 2013; Išoraitė 2013; Prause, Hunke 2014; Tvaronavičienė 2014; Garškaitè-Milvydienė 2014; Figurska 2014; Dzemyda, Raudeliūnienè 2014; Tarabkova 2014; Raudeliūnienè et al. 2014; Vasiliūnaitė 2014; Tunčikienė, Drejeris 2015; Giessen 2015; Išoraitè 2015; Goyal, Sergi 2015). Motivational factors are crucial in order to analyse and understand why "working-in" and "remaining-in" NFP organisations despite facing worse working and economic conditions than in the for-profit labour market (Caurkubule, Rubanovskis 2014; De Alencar, Almeida 2013; Moskvina 2013). 
Most managers assume that employees perform based on the level of reward. However, too often monetary factors are considered to be the most significant ignoring intrinsic motivation and its relation to performances. It is well known that money is the most debated aspect of motivation. Gupta and Mitra (1998) argue that monetary incentives are strong motivators and they established that "financial incentives were particularly powerful with respect to performance quantity" (Tippet and Kluvers 2009: 7). However, the main common finding is that people work and are retained in NFP organisations not primarily because of rewards but because of intrinsic factors as the main driving force (Schepers et al. 2005; Tunčikienè, Drejeris 2015; Giessen 2015; Išoraite 2015, Išoraitè et al. 2014). Furthermore, it has been argued that the need for people to be employed in a particular organisation is largely based on "human motivation" (Tippet and Kluvers 2009: 8; Laužikas, Mokšeckienė 2013; Moskvina 2013; Wahl, Prause 2013; De Alencar, Almeida 2013; Išoraitė 2013; Prause, Hunke 2014; Tvaronavičienė 2014). In a case study about non-profit organisations argue that people join and work for such organisation (i.e. NFP) because they are more inclined to intrinsic rather than extrinsic motivation such as the financial rewards.

\section{Methodology}

Given the gained benefits, many recent studies in social research have adopted a case study approach (Yin 2002), so have we. Our initial assumption has been that people work in the NFP organization (specifically the two in the case study), not for the prospects of financial gain as a main driver. We have taken into account Saunders' theory relative to the possibility of a "formulation regarding the cause and effect relationships between two or more variables which may not have been tested" (Saunders et al. 2009: 602) and drafted a work-hypothesis. As the case study allows the use of many sources to collect the data, a questionnaire survey was formulated so as to gather as much as possible evidence in relation to the motivational aspects of the respondents. Purposive sampling has been used as it is recommended when the selected organisations are representative and can answer the research questions (Saunders et al. 2009). Interviews were used to triangulate the data and for validation purposes Bell (2005). Interview was conducted face to face, while questionnaires were sent to the respondents. The work-hypothesis related to Company-A and Company-B was that the "non-monetary motivational factors were key for personnel retention, engagement and performance levels despite the large gaps and shortcomings spotted in respect of Hygiene Factors".

\section{Data analysis and selected sample}

The sample size of 100 employees was obtained using random sampling techniques from the sample frame of 4500 Company-A employees. A total of 100 and 50 questionnaires were sent to Company-A and Company-B respectively. In total 88 completed questionnaires were collected from 150 questionnaires that were distributed, which is 59\% compound response rate from Company-A and Company-B (see Table 1). In Company-B out of 50 employees who received the questionnaires, only 20 questionnaires were returned which is $40 \%$ and is relatively lower than in Company-A but still meets the minimum requirement for a response rate of higher or equal to $30 \%$ recommended in social science research (Bryman 2008). Random sampling was chosen because it provides an equal chance of each employee in the sample frame of the 4550 population to be selected. For Company-A the representative sample is $\mathrm{N} 1=68$, and for Company-B $\mathrm{N} 2=20$, both samples are representative and this allows some generalisation of the findings (Denscombe 2003).

Table 1. Respondents for Questionnaire survey in Companies A and B

\begin{tabular}{|l|l|l|l|}
\hline Organisation & Sample size & Respondents & Response Rate (\%) \\
\hline Company-A & 100 & 68 & $68 \%$ \\
\hline Company B & 50 & 20 & $40 \%$ \\
\hline Total & $\mathbf{N = 1 5 0}$ & $\mathbf{N}=\mathbf{8 8}$ & $\mathbf{5 9 \%}$ \\
\hline
\end{tabular}

Source: Denscombe (2003)

To complement the quantitative data collected from questionnaires, a series of interviews with support workers, senior support workers and line managers were conducted. The interviews involved people from both 
Company-A and Company-B. A total of 23 people were interviewed with the majority of the respondents from Company-A. The interview helped in triangulation and validation of the information obtained in the questionnaire-based survey. Aspects related to ethical considerations were taken into account. Consent forms were signed and respondents in the questionnaire survey and interviews were free to decline or participate in the research. While the directors of the companies allowed the collection of data, consent for the use of the real names was denied. The questionnaire was formulated including 31 questions. The questions were coded and gathered data was processed using SPSS 17 statistical package software. The analysis used frequency tables, correlations and cross-tabulations. Out of the total 88 respondents $(\mathrm{N}=88)$, the majority were from Company-A (77\%). This implies that care should be taken in comparing the two organisations, therefore, an indexing, or proportional approach, has been considered as meaningful rather than a direct figure comparison which would not account for the above mentioned disparity.

\section{Gender distribution analysis}

In this study the gender profile of respondents in both organisations show that Males are $34 \%$ while Females are $63 \%$ while some respondents declined to mention their gender. Findings from Company-A show that the company has a rich diversity of employees in different positions ranging from support workers to managerial levels (Table 2).

Table 2. Company-A diversity table: gender, ethnicity and disability*

\begin{tabular}{|c|c|c|c|c|c|c|c|c|c|c|c|c|c|}
\hline \multirow[b]{2}{*}{ Job title } & \multirow[b]{2}{*}{ Headcount } & \multicolumn{2}{|c|}{ Gender (\%) } & \multicolumn{7}{|c|}{ Ethnic Origin (\%) } & \multicolumn{3}{|c|}{ Disability (\%) } \\
\hline & & M & $\mathbf{F}$ & White & Mixed & Asian & Black & Chinese & $\begin{array}{c}\text { Not } \\
\text { Known }\end{array}$ & Other & Yes & No & $\begin{array}{l}\text { Refuse to say } \\
\text { / not known }\end{array}$ \\
\hline Support Worker & 2660 & $27.9 \%$ & $72.1 \%$ & $62.6 \%$ & $1.3 \%$ & $2.0 \%$ & $17.4 \%$ & $0.1 \%$ & $15.7 \%$ & $80.0 \%$ & $1.6 \%$ & $60.1 \%$ & 1020 \\
\hline Senior Support Worker & 285 & $27.4 \%$ & $72.6 \%$ & $70.5 \%$ & $1.8 \%$ & $1.4 \%$ & $17.9 \%$ & $0.0 \%$ & $7.4 \%$ & $1.1 \%$ & $0.7 \%$ & $42.8 \%$ & 161 \\
\hline Deputy Team Manager & 79 & $17.7 \%$ & $82.3 \%$ & $64.6 \%$ & $0.0 \%$ & $2.5 \%$ & $5.1 \%$ & $1.3 \%$ & $25.3 \%$ & $1.3 \%$ & $0.0 \%$ & $46.8 \%$ & 42 \\
\hline Team Leader/Manager / Home Manager & 286 & $19.2 \%$ & $80.8 \%$ & $76.9 \%$ & $0.7 \%$ & $1.0 \%$ & $4.9 \%$ & $0.0 \%$ & $16.1 \%$ & $0.3 \%$ & $1.0 \%$ & $38.5 \%$ & 173 \\
\hline Area Manager & 52 & $25.0 \%$ & $75.0 \%$ & $84.6 \%$ & $0.0 \%$ & $1.9 \%$ & $1.9 \%$ & $1.9 \%$ & $9.6 \%$ & $0.0 \%$ & $0.0 \%$ & $21.2 \%$ & 41 \\
\hline Regional Director \& above & 21 & $38.1 \%$ & $61.9 \%$ & $81.0 \%$ & $0.0 \%$ & $0.0 \%$ & $0.0 \%$ & $0.0 \%$ & $19.0 \%$ & $0.0 \%$ & $0.0 \%$ & $33.3 \%$ & 14 \\
\hline Admin staff not NDGL & 44 & $9.1 \%$ & $90.9 \%$ & $84.1 \%$ & $2.3 \%$ & $2.3 \%$ & $2.3 \%$ & $0.0 \%$ & $9.1 \%$ & $0.0 \%$ & $4.5 \%$ & $63.6 \%$ & 14 \\
\hline Other & 65 & $33.8 \%$ & $66.2 \%$ & $89.2 \%$ & $1.5 \%$ & $0.0 \%$ & $1.5 \%$ & $0.0 \%$ & $7.7 \%$ & $0.0 \%$ & $10.8 \%$ & $47.7 \%$ & 27 \\
\hline NDGL Staff & 166 & $30.7 \%$ & $69.3 \%$ & $81.3 \%$ & $6.0 \%$ & $6.0 \%$ & $3.0 \%$ & $0.0 \%$ & $6.6 \%$ & $2.4 \%$ & $2.4 \%$ & $43.4 \%$ & 90 \\
\hline Total Staff & 3658 & $27.0 \%$ & $73.0 \%$ & $66.4 \%$ & $1.2 \%$ & $2.1 \%$ & $14.8 \%$ & $0.1 \%$ & $14.6 \%$ & $1.6 \%$ & $1.6 \%$ & $55.1 \%$ & 1582 \\
\hline Highest earning $5 \%$ & 183 & $35.0 \%$ & $65.0 \%$ & $73.8 \%$ & $0.5 \%$ & $3.8 \%$ & $4.9 \%$ & $0.5 \%$ & $15.3 \%$ & $0.5 \%$ & $0.5 \%$ & $42.1 \%$ & 105 \\
\hline
\end{tabular}

Source: HR Dept. Company-A as per 31st Dec 2010

The majority of support workers (62.6\% support workers and $70 \%$ of senior support workers) are from white ethnic background, followed by black (17.4\% support workers and $17.9 \%$ senior support workers). These first two groups make $80 \%$ of the Support worker group and $88 \%$ of the Senior support workers group. The third group was labelled as "not known" and it includes those who refused to answer. Further analysing the data it is noticeable that group represented by employees of white ethnic background have a proportional representation in the various roles including managerial ones, the black ethnic group has a greater presence in the support worker and senior support workers segment. One of the reasons might be due to the fact that a higher percentage of the black ethnic group has a higher turnover due to various external circumstances not depending from Company-A. This could be objective of further analysis and investigation. Employees of Asian and Chinese ethnic background are by far less than other overall therefore their distribution between the various managerial and non-managerial roles is statistically less relevant as it could be greatly influenced by one individual's career, yet they have a normally distributed proportion between managerial and non-managerial positions, team leaders, deputy managers, area managers, regional directors and etc.).

\section{Education/qualification and experience at entry distribution analysis}

The study also asked respondents about their qualification levels at entry in the both organisations. Results indicate that $27 \%$ of respondents joined the companies with "O" level/GCSE qualifications, and only $16 \%$ had "A" levels. Those with NVQ or vocational skill were $29 \%$, a slightly higher than those employees with GCSE 
qualifications. And $28 \%$ of the employees are without any education qualifications. In relation to the motivation for joining a company, the results confirm that for a good part of the sample, one of the reasons to work in either company was their relative ease of entry. This implies that even people without formal qualifications could still join the organisations (as indicated by a $29 \%$ proportion of employees having no formal education and or vocational qualifications). This principle is also part of the human resource policy of both Company-A and Company-B and proved to be a significant motivation for people in joining the company. The results show that "word of mouth" also helps to project the company image towards the outer world and therefore many of the people who become inwardly motivated attracted through extrinsic factors others to enter and work both in Company-A and Company-B.

In this study it has been possible to compare and examine responses of people with a work experience from 1-5 years, 6-7, 8-10, 10+ years, or not at all. The results show that $34 \%$ of respondents indicated to have no work experience, followed by those with $1-5$ years of experience $(26 \%)$ and over 10 years of experience (26\%). A small proportion (14\%) of respondents had experience of 6-10 years. These results prove the fact that entry criteria are non-discriminatory in both Company-A and Company-B, and this is to be considered crucial because talented (potential employees) are not left out due to lack in qualifications. This translates in the fact that their aptitude to work is regarded as a very important motivation factor (which is intrinsic in nature) and can be effective in determining work performance. Moreover both companies use the same approach to recruit even those people not only without experience (34\%) but also without vocational or formal education (29\%). It is apparent that the two organisations under exam attract prospective employees also because they make them feel not-discriminated in any respect. The employees are encouraged towards self-development and this provides room also for those without any qualification. The respondents were also asked how many years they have worked in Company-A and Company-B respective results show that $15 \%$ had a work experience of 2 years. Those with 1-2 years of work experience were $23 \%$ while those with $1-5$ years were $48 \%$ and those above 5 years of experience were 52\%. A $60 \%$ of the respondents had previously worked in 1 to 4 different organisations. A $40 \%$ of employees in Company-A and Company-B worked in more than 4 different work places. Combining this information it can be argued that most of the people who joined the two companies had previous experience of moving from one company to another either for dissatisfaction or lack in motivation.

\section{Employees' attitude}

A $70 \%$ of employees are full time and $30 \%$ part time. As far as the relevance of training is concerned, the study show that $67 \%$ of employees feel that the training they received on the job was significant. The attitude of staff towards training and career opportunity was stressed by $47 \%$ of respondents who strongly agreed. Those having a positive attitude towards equal opportunity in training offered by the Company-A accounted for a 74\%, while $20 \%$ had a negative attitude. Employees' perception of belonging to the organisation was indicated only by a relatively small proportion, $29 \%$, while $71 \%$ felt that they were not part of the organisations. According to the insight from qualitative data, this could be due to lack of recognition or status, within their jobs. Furthermore, employees may have routine jobs and not be involved in decision making. Despite this, most respondents have positive attitude towards their job context, and work environment as per data in Figure 1.

Company-A (extrinsic)
Company-B (extrinsic)
Self-motivated (intrinsic)
Clean environment
Discuss problems
Enjoy work
Right job

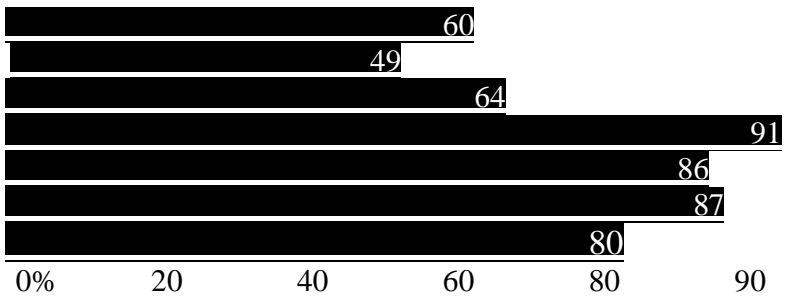

$100 \%$

Fig.1. Motivation distribution $\%$ of respondents Source: author

A clean environment scored 91\% (showing the relevance of Herzberg's Hygiene factor). Likewise, a majority of 
$80 \%$ respondents reported feeling to be in right job. Additionally, the results on self-motivation (intrinsic motivation) suggest supporting a correlation between feeling to be in the right job and being motivated as $86 \%$ of respondents were of the opinion that they are intrinsically motivated, with Company-B performing better than Company-A, in respect of providing motivation to their employees.

\section{Employee's rewards}

In the interview with the management emerged that Company-A could not pay enough money simply because "the company does not make money" (verbatim form the interviews), yet it was noted that though the Company-A did not pay enough money, employees still want to work in the organisations. The results have indicated that $50 \%$ of Company-A and Company-B employees were of the opinion that the wages were fair. However, a $40 \%$ thought the wages were unfair but there were overriding factors which could retain them within the organisation. One of the dominant factors that emerged was training. Another major factor was job retention/security as while many employees entered without qualifications, they would have limited prospects for relocation elsewhere. Employees in both companies indicated that they wanted more training hours (65\%) even if over $50 \%$ of employees need to attend non-mandatory health and social care training.

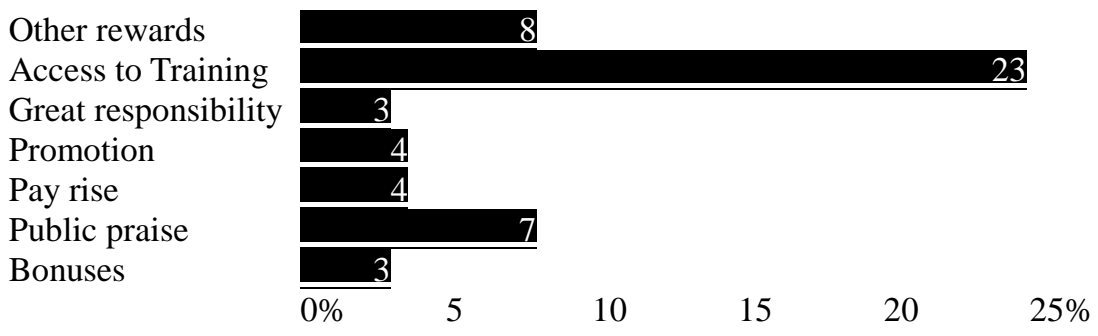

Fig.2. Motivation factors in Company-A and Company-B (\% responses)

Source: author (multiple response)

The data from Figure 2 illustrate that company access to training is the main reward which employees perceive as a motivation factor. Other motivation factors ranked second with $8 \%$. The recognition in the form of public praise ranked third with 7\%. Promotion and pay rise had same proportion of responses $4 \%$ and bonuses and great responsibility are least viewed as motivation factors with only $3 \%$ each. The findings appear in line with both Maslow's (1987) and Herzberg's (2003) theories on motivation. This study points out that the self-motivated employees represent $64 \%$ which implies that the examined organisations benefit from employees internal motivations and are rewarded by having placed a great emphasis on responsibility of the employees. Motivation should be incentivised by means of some form of reward which could be financial and/or non-financial. The same could be said for non-reward based incentives which could still be financial and/or non-financial. The study has pointed out that:

1. Both companies provide some direct or indirect financial benefit.

2. Both companies have a substantial program of trainings.

3. Both companies give public recognition to employees' achievements.

4. Both companies have a relatively lower pay than equivalent for profit organisation. However, Company-A receives funds from local authorities only while Company-B receives funds from local and central authorities. Thus, Company-A funds are smaller and less certain than those of Company-B.

5. Company-B employees salary is about $15 \%$ higher than Company-A, moreover, Company-B employees get more holiday pay than Company-A.

6. Company-B employees enjoy their work more and they feel more part of the "team" than those of Company-A

7. Senior support workers/managers in Company-A may be required to work overtime but will only be paid as much as a simple support worker for the extra hours worked.

8. Company-A is a big company delivering its services in various locations and the employees have to work in different places and alone increasing the negative impact on employees' motivation. On the contrary in 
Company-B there is more social life as there is just one site where Company-B delivers its services.

In conclusion, Company-B has an overall better performance in motivating its staff than Company-A. Most profit making organisations have very stringent entry criteria for employment, while many NFP have relatively flexible criteria which permit much diversity of background factors such as education and qualifications, skills, experience, age and gender. These factors appear to not only attract but also they have a decisive role in employees' retention.

\section{Analysis of Motivation \& Performance}

Motivation is an increasingly important factor in the performance of both for-profit and non-profit organisations. Many enterprises recognise this by adopting specific measures designed to optimize staff motivation. In any organisation, there can be significant variation in contributions made by individuals, as shown by Bratton et al. (2010:191). In the two organisations there are no strict entry criteria which dominate the recruitment process. In both organisation education and qualifications are not restrictive profile criteria. Car ownership requirement are not present and equal opportunity to access training is perceived as a motivation incentive. Maslow (1943), Herzberg (1968), and Hackman and Oldham (1976) all argue that the job context, or what Torrington et al. (2008) calls it the "work itself", is an important factor for enhancing employees' motivation. Job satisfaction is perceived as one of the important element for employees' satisfaction. A number of studies have discussed job satisfaction with work performance (Purcell et al. 2003) and all arrive at a consensus that job satisfaction impacts on performance. In the case of the present study, findings indicate that this applies in the $80 \%$ of the cases. Maslow (1943) stress the importance of affiliation as one of the motivation drivers. The results of the present study show that a small proportion of employees feel that they were part of the organization thus showing that there is a clear problem with the extent of employees' involvement. The study also found that both companies needed to implement a policy which encourage and enhances team work and also involves employees in decision making. Many argue that money is not a motivation factor; however, findings of this study show that a $44 \%$ of employees replied that the pay was not fair (both in Company-A and Company-B).

\section{Motivation in Company-A}

It grants at least 20 days annual leave per year even if more can be provided depending on the employee's performance and permanence in the company (up to a maximum number of total paid holidays of 32 days thanks to the possible addition of one extra day for each year an employee has been in the company for at least 12 years). One of the extrinsic motivating factors is that flexible hours enable women to achieve greater balance between duties at work and at home. This aspect was reinforced by the fact that Company-A has adopted a scheme for discounted store cards from large retailers' organisations such as Cosco and Makro. Company-A employees benefit from a relatively good pension scheme and have access to on-line training facilities and this is perceived as motivational. Additionally, Company-A has established a forum where employees discuss issues pertaining to the work. The forum is called "Evolution" and is perceived as an incentive. Every three month the forum holds an event in which goals are set, it is possible to learn from each other's experience, and to nominate the best staff who will be awarded a small trophy. The employees rated the discussion at Evolution meetings long with the work place as highly motivational. However, Company-A lacks motivation bonuses, and managers somehow do not recognise employees (except for what is achieved via the "evolution" approach).

\section{Motivation in Company-B}

Company B employees' incentives include job security, good pay and contract as well as normal working hours Monday to Friday. Employees are provided with trainings on a monthly basis. The quality, and quantity, of training will depend on their development's needs (with some even regarded as mandatory). Additionally, employees are also entitled to holiday and sick pay (which is not always the case in this kind of working environment). The work environment is good and team-work is the norm. This was reflected in $60 \%$ of employees feeing motivated. The rewards in Company-B include a good pension (every employee can get private pension contributions scheme). Pay is relatively higher than in Company-A (if calculated on an hourly 
basis), however, employees in Company-A have more opportunities to receive additional pay for each extra hour worked.

\section{Conclusions}

The purpose of the present study was to explore the role of motivations in non-for-profit organisations. Specifically it reports the findings of two case studies conducted in the health and social care service provision for supporting people with learning disabilities and autism in the UK. Earlier studies on motivations in NFP organisations have established that, pay in these organisations is relatively lower compared to people working in the for-profit sector. In this respect, the present study conforms to other researches on what they concluded that despite lower pay people work in non-profit organisations because of the importance they attribute to these jobs. The study has confirmed that the main driver for people to enter and work in non-profit organisations is their individual intrinsic motivation. Furthermore, it pointed out a remarkable phenomenon that is: the role of motivation is inversely proportional to the size of the company, in other words as the company's human resource increases in size the motivation becomes weaker. Hence it can be inferred that small organisations are more likely to motivate employees than large organisations. What just stated is substantiated by the following findings: while Company-B has an estimated 6\% of employees of Company-A, in Company-A only 29\% of employees are motivated, whereas in Company-B this percentage rises to a $60 \%$. Therefore the rates of employees' motivation in Company-A and Company-B can be deduced to be 1:2. Many factors can account for this scenario, they include employees' team work and the feeling experienced in small organisations, where employees tend to be more close to each other than in large organisations. However, given the nature of the analysis of the present study, there are limitations to the possibility for a generalisation of the findings related to the underlying causes of the relationship between motivation and company size. Hence this is an area for further research. This study has confirmed that non-monetary incentives are perceived higher as motivation factors by employees, and the conclusion) is that intrinsic motivations are overriding objectives for people working in non-profit organisations. Likewise, it has proven that where managers have embraced Theory Y as leadership style, they have increased motivation and performance as well as overall company competitive advantage (Cottrell 2003; Purcell 2003).

While organisations have an important role to play, intrinsic motivation drives employees to seek motivation beyond their organisations. The conclusion that can be derived is that organisation must also understand what motivational factors are offered by competitors. Intrinsic and extrinsic motivation appeared to contribute to people working in the NFP organisation with intrinsic factors dominating the motivation factors, while extrinsic ones are largely seen as external factors and relatively lower compared to all intrinsic variables of motivations. In Company- $\mathrm{A}$ and Company-B there is a differential on how employees perceived their organisations as motivating factors, empirical evidence have shown that $30 \%$ employees perceive that they are motivated by Company-A while $60 \%$ by Company-B. According to scientists (Armstrong 2006; Torrington et al. 2008; Caurkubule, Rubanovskis 2014; De Alencar, Almeida 2013; Išoraitė 2013; Moskvina 2013) HRM policies have addressed the issue of motivation, however, the study proved that $64 \%$ of respondents are intrinsically motivated while company motivation was found to be low, employees were not satisfied with the pay, and yet over $85 \%$ enjoy this kind of work and feel listened.

\section{References}

Armstrong, M. 2006. Strategic Human Resource Management. 3rd Edition. London: Kogan Page.

Bell, J. 2005. Doing your research project: A guide for first time researchers in Education, health and social sciences. 4th edition. England: Open University Press.

Bratton, J.; Sawchuk, P.; Forshaw, C.; Callinan, M.; Corbett, M. 2010. Work \& Organizational behaviour. 2nd edition. Basingstoke: Palgrave Macmillan.

Bryman, A. 2008. Social Research Method. 3rd edition. Oxford: Oxford University Press.

Cooke, F. L. 2000. Human resource strategy to improve organisation performance. A route for British firms. Working paper 9, Economic and social research council. Swindon: Future of work programme. 
Cottrell, S. 2003. Skills for Success: The personal Development Planning Handbook. Basingstoke. Palgrave McMillan.

Caurkubule, Ž.; Rubanovskis, A. 2014. Sustainable entrepreneurship through motivation: case of Latvian companies, Entrepreneurship and Sustainability Issues 2(1): 43-48. DOI: http://dx.doi.org/10.9770/jesi.2.1(6)

De Alencar, L.M.; Almeida, H.N. 2013. Economic viability and sustainability of solidarity economy enterprises: a case study on the technological incubator of popular cooperatives of the Catholic University of Salvador, Entrepreneurship and Sustainability Issues 1(2): 92-98. DOI: http://dx.doi.org/10.9770/jesi.2013.1.2(3)

Denscombe, M. 2003. The good Research Guide. Second Edition: for small-scale social research projects. Maidenhead. Open University Press.

Dzemyda, I.; Raudeliūnienè, J. 2014. Sustainable youth entrepreneurship in conditions of global economy toward energy security, Entrepreneurship and Sustainability Issues 1(4): 247-256. DOI: http://dx.doi.org/10.9770/jesi.2014.1.4(7)

Figurska, I. 2014. Sustainable entrepreneurship: localization, acquiring and use of knowledge sources in competitive organization, Entrepreneurship and Sustainability Issues 1(4): 210-222. DOI: http://dx.doi.org/10.9770/jesi.2014.1.4(3)

Garškaitè-Milvydienė, K. 2014. Anti-crisis management of enterprises and possibilities of overcoming their critical condition, Entrepreneurship and Sustainability Issues 1(4): 187-203. DOI: http://dx.doi.org/10.9770/jesi.2014.1.4(1)

Giessen, H.W. 2015. Sustainable entrepreneurship and peculiarities of media-based learning, Entrepreneurship and Sustainability Issues 2(3): 154-162. DOI: http://dx.doi.org/10.9770/jesi.2014.2.3(4)

Goyal, S.; Sergi, B.S. 2015. Social entrepreneurship and sustainability - understanding the context and key characteristics, Journal of Security and Sustainability Issues 4(3): 269-278. DOI: http://dx.doi.org/10.9770/jssi.2015.4.3(7)

Gupta, N.; Mitra, A. 1998. The Value of Financial Incentives, ACA Journal (autumn): 58-66.

Hackman, J.; Oldham, G. 1976. Motivation through the design of work, test of theory, Organisational behaviour and human performance 16: $250-279$.

Herzberg, F. 1968. One more time, how do you motivate employees, Harvard business review 46: 53-62. Available on the Internet: http://www.ccsenet.org/journal/index.php/ijbm/article/view/181

Herzberg, F. 2003. One More Time: How Do You Motivate Employees? Harvard Business Review 81(1): 87 - 96. Available on the Internet: http://maaw.info/ArticleSummaries/ArtSumHerzberg6803.htm

Išoraitè, M. 2015. Entrepreneurship and blog marketing, Entrepreneurship and Sustainability issues 2(3): 171-178. DOI: http://dx.doi.org/10.9770/jesi.2014.2.3(6)

Išoraitė, M. 2013. Motivation tools though lenses of prospective employees, Entrepreneurship and Sustainability Issues 1(2): 116-123. DOI: http://dx.doi.org/10.9770/jesi.2013.1.2(6)

Išoraitė, M.; Steiblienè, L.; Mečèjienè, G. 2014. If obtained professional competences are suitable for sustainable entrepreneurship: case of Vilnius University of Applied Sciences, Entrepreneurship and Sustainability Issues 1(4): 239-246. DOI: http://dx.doi.org/10.9770/jesi.2014.1.4(6)

Laužikas, M.; Mokšeckienè. 2013. The role of creativity in sustainable business, Entrepreneurship and Sustainability Issues 1(1): 10-22. DOI: http://dx.doi.org/10.9770/jesi.2013.1(2)

Maslow, A. H. 1943. A theory of Human Motivation, Psychology Review 50: 370-396.

Maslow, A. H. 1987. Motivation \& Personality. Third Edition. Harper \& Row.

Moskvina, J. 2013. Social enterprises as a tool of social and economic policy, Entrepreneurship and Sustainability Issues 1(1): 45-54. DOI: http://dx.doi.org/10.9770/jesi.2013.1.1(5)

Prause, G.; Hunke, K. 2014. Sustainable entrepreneurship along green corridor, Entrepreneurship and Sustainability Issues 1(3): 124-133. DOI: http://dx.doi.org/10.9770/jesi.2014.1.3(1)

Purcell, J.; Kinnie K.; Hutchinson, S.; Rayton, B.; Swart J. 2003. Understanding the People and Performance Link: Unlocking the Black Box. London. CIPD. 
Raudeliūnienè, J.; Tvaronavičienè, M.; Dzemyda, I.; Sepehri, M. 2014. Sustainable entrepreneurship through energy stewardship: role of values and behavioral patterns, Entrepreneurship and Sustainability Issues 2(2): 107-117. DOI: http://dx.doi.org/10.9770/jesi.2014.2.2(6)

Saunders, M.; Lewis, P.; Thornhill, A. 2009. Research Methods for Business Students. Fifth edition. Harlow. Pearson Education Limited.

Schepers, C.; De Gieter, S.; Pepermans, R.; Du Bois, C.; Caers, R.; Jegers, M. 2005. How Are Employees of the Non-profit Sector Motivated? Nonprofit Management \& Leadership 16(2): 191-208.

Tarabkova, L. 2014. Model of motivating linked-up with education, Entrepreneurship and Sustainability Issues 2(1): 12-18. DOI: http://dx.doi.org/10.9770/jesi.2014.2.1(2)

Tippet, J.; Kluvers, R. 2009. Employee rewards and motivation in non-profit organisations. Case study from Australia, International Journal of Business and Management 4(3). Available on the Internet: http://www.ccsenet.org/journal/index.php/ijbm/article/view/181

Torrington, D.; Hall, L.; Taylor, S. 2008. Human Resource Management. London. Pearson Education/FT Prentice Hall.

Tunčikienè, Ž.; Drejeris, R. 2015. Entrepreneurship ecosystem: methodological approaches to functions' review of public sector institutions, Entrepreneurship and Sustainability Issues 2(3): 118-132. DOI: http://dx.doi.org/10.9770/jesi.2014.2.3(1)

Tvaronavičienè, M. 2014. If industrial sector development is sustainable: Lithuania compared to the EU, Entrepreneurship and Sustainability Issues 1(3): 134-142. DOI: http://dx.doi.org/10.9770/jesi.2014.1.3(2)

Vasiliūnaitè, R. 2014. Sustainable development: methodological approaches toward issues, Journal of Security and Sustainability Issues 3(3): 69-75. DOI: http://dx.doi.org/10.9770/jssi.2014.3.3(6)

Wahl, M.; Prause, G. 2013. Toward understanding resources, competencies, and capabilities: business model generation approach, Entrepreneurship and Sustainability Issues 1(2): 67-80. DOI: http://dx.doi.org/10.9770/jesi.2013.1.2(1)

Yin, R. K. 2002. Case Study Research Design and Methods. Third Edition Applied Social Research Method Series Volume 5. California, Sage Publications, Thousand Oaks.

Li SUN is a qualified Support Worker (with direct administrator support to Management) since 2008, working with adults with learning disabilities, providing full living support, guidance/training and provide mobility and financial support, participating in various activities both for the individual and groups. $\mathrm{Li}$ is also Administrative/Office Support to Management staff and offices. Li is also supporting children with special needs in improving quality of life. Li is also a bi-lingual, MBA qualified (with distinction) Teaching certificate, QCF level 3 certificate.

Dr. David Luigi FUSCHI is PhD with almost 30 years of experience, Director \& Chairman at Bridging Consulting Ltd, member of the Professional Advisory Board of HP-MOS, Senior member of IEEE and ACM, and Project Expert for 12 Research Programmes. A track record of over 98 projects successful completion (12 rescued), acquisition of over 20 projects, and over 100 projects assessed. Strong connection with industry and academia. A good experience in teaching and knowledge transfer. Published a book chapter and the market analysis adopted as the starting point of the EC Special Task Force for Multimedia \& Education, several scientific articles, position papers, and very successful tutorials

This is an open access journal and all published articles are licensed under a Creative Commons Attribution 4.0 International License 